\title{
Association of AXIN2 gene polymorphisms with nonsyndromic oligodontia in Turkish families \\ Nuriye Dinckan ${ }^{1,3}$, Zehra Oya Uyguner ${ }^{1}$, Hulya Kayserili ${ }^{2}$, Ariadne Letra ${ }^{3,4}$
}

\author{
${ }^{1}$ Department of Medical Genetics, Istanbul Medical Faculty, Istanbul University, Istanbul, 34093, Turkey \\ ${ }^{2}$ Department of Medical Genetics, Koc University, School of Medicine (KUSOM), Istanbul, 34010, Turkey \\ ${ }^{3}$ Department of Diagnostic and Biomedical Sciences and Center for Craniofacial Research, University of Texas Health Science Center at Houston School of Dentistry, \\ Houston, TX, 77054, USA \\ ${ }^{4}$ Pediatric Research Center, University of Texas Health Science Center at Houston McGovern Medical School, Houston, TX, 77030, USA
}

\section{Abstract}

Tooth agenesis is the most common developmental abnormality of the human dentition characterized by the congenital absence of one or more permanent teeth. Oligodontia is the term used to describe severe tooth agenesis, where six or more permanent teeth are missing. The WNT gene pathway regulates multiple developmental processes during craniofacial and tooth development, and variations in WNT pathway genes have been reported in individuals with tooth agenesis. In this study, we investigated the association of 37 SNPs in/nearby 12 WNT pathway genes (WNT3, WNT3A, WNT5A, WNT8A, WNT9B, WNT10A, WNT11, AXIN1, AXIN2, APC, LRP5, LRP6) with oligodontia in 22 multiplex families. Genotypes were generated using Taqman chemistry in a real-time polymerase chain reaction assay. Family-based association tests were performed using FBAT. Pairwise-haplotype analysis was also performed. Bonferroni correction was used to adjust for multiple testing and Pvalues $\leq 0.001$ were considered statistically significant. We found nominal association for AXIN2 rs7591, located in the $3^{\prime}$ UTR, with oligodontia $(P=0.04)$. In silico analysis of SNP function predicted a binding site for miR-205 with potential impact on AXIN2 expression. Although modest, these results continue to support a role for AXIN2 in the etiology of familial tooth agenesis.
Citation: Dinckan, et al. (2016). Association of AXIN2 gene polymorphisms with nonsyndromic oligodontia in Turkish families. Dentistry 3000. 1:a001 doi:10.5195/d3000.2016.57

Received: July 19, 2016

Accepted: August 1, 2016

Published: October 3, 2016

Copyright: (2016 Dinckan, et al. This is an open access article licensed under a Creative Commons Attribution Work 4.0 United States License.

Email: ariadne.m.letra@uth.tmc.edu

\section{Introduction}

Tooth agenesis is the most common craniofacial congenital malformation in humans [1]. Up to $20 \%$ of the general population has agenesis of at least one third molar. Agenesis of other permanent teeth, excluding third molars, ranges from $\sim 1.6$ to $9 \%$, depending on the population studied, and in $70-80 \%$ of these cases one or two teeth are missing $[2,3]$. Tooth agenesis can be identified as hypodontia (up to 5 teeth missing, excluding third molars), or oligodontia (lack of more than 6 teeth missing, excluding third molars)
[1], in sporadic cases or segregating in families. In most of the familial cases, inheritance is autosomal dominant, however, autosomal recessive and $\mathrm{X}$-linked inheritance have also been described [4]. 
Vol 4, No 1 (2016) DOI 10.5195/d3000.2016.57

The etiology of

\begin{tabular}{|c|c|c|c|c|c|c|}
\hline Family No. & Individual No. & Phenotype & Relationship & $\begin{array}{c}\text { No. of } \\
\text { Missing } \\
\text { Teeth }\end{array}$ & $\begin{array}{l}\text { Type of Missing } \\
\text { Teeth }\end{array}$ & Inheritance \\
\hline \multirow[t]{8}{*}{1} & $1-1$ & Oligodontia & Proband & 11 & Incisors, premolars & Complex \\
\hline & $1-2$ & Unaffected & Mother & 0 & & \\
\hline & $1-3$ & Unaffected & Father & 0 & & \\
\hline & $1-4$ & Unaffected & Brother & 0 & & \\
\hline & $1-5$ & Unaffected & Brother & 0 & & \\
\hline & $1-6$ & Oligodontia & Aunt & 10 & & \\
\hline & $1-7$ & Oligodontia & Uncle & 7 & & \\
\hline & $1-8$ & Oligodontia & Uncle & 7 & & \\
\hline \multirow[t]{15}{*}{2} & $2-1$ & Oligodontia & Proband & 28 & $\begin{array}{l}\text { Incisors, canines, } \\
\text { premolars, molars }\end{array}$ & Complex \\
\hline & $2-2$ & Unaffected & Mother & 0 & & \\
\hline & $2-3$ & Oligodontia & Father & 8 & & \\
\hline & $2-4$ & Unaffected & Brother & 0 & & \\
\hline & $2-5$ & Hypodontia & Sister & 4 & & \\
\hline & $2-6$ & Hypodontia & Brother & 4 & & \\
\hline & $2-7$ & Unaffected & Brother & 0 & & \\
\hline & $2-8$ & Unaffected & Sister & 0 & & \\
\hline & $2-9$ & Hypodontia & Brother & 5 & & \\
\hline & $2-10$ & Oligodontia & Uncle & 7 & & \\
\hline & $2-11$ & Hypodontia & Aunt & 5 & & \\
\hline & $2-12$ & Oligodontia & Cousin & 21 & & \\
\hline & $2-13$ & Oligodontia & Cousin & 23 & & \\
\hline & $2-14$ & Oligodontia & Cousin & 19 & & \\
\hline & $2-15$ & Oligodontia & Cousin & Unk & & \\
\hline \multirow[t]{8}{*}{3} & 3-1 & Oligodontia & Proband & 20 & $\begin{array}{c}\text { Incisors, premolars, } \\
\text { molars } \\
\end{array}$ & $\mathrm{AR}$ \\
\hline & $3-2$ & Unaffected & Mother & 0 & & \\
\hline & 3-3 & Oligodontia & Father & Unk & & \\
\hline & $3-4$ & Hypodontia & Sister & Unk & & \\
\hline & 3-5 & Unaffected & Sister & 0 & & \\
\hline & $3-6$ & Hypodontia & Brother & Unk & & \\
\hline & 3-7 & Oligodontia & Sister & 17 & & \\
\hline & 3-8 & Hypodontia & Cousin & Unk & & \\
\hline \multirow[t]{7}{*}{4} & $4-1$ & Oligodontia & Proband & 8 & $\begin{array}{c}\text { Lower incisors, } \\
\text { molars }\end{array}$ & $\mathrm{AD}$ \\
\hline & $4-2$ & Unaffected & Mother & 0 & & \\
\hline & 4-3 & Unaffected & Father & 0 & & \\
\hline & 4-4 & Hypodontia & Brother & 4 & & \\
\hline & 4-5 & Hypodontia & Aunt & Unk & & \\
\hline & 4-6 & Unaffected & Cousin & 0 & & \\
\hline & $4-7$ & Hypodontia & Grandmother & Unk & & \\
\hline
\end{tabular}

tooth agenesis is complex and poorly understood [4]. Studies in mice have allowed the identification of genes directly or indirectly involved in the regulation of tooth development, and have been fundamental to the understanding of the basic genetic principles of tooth development and its defects [5]. Nevertheless, very few human mutations have been described in several genes known to arrest tooth development in mice. This may reflect basic differences in agenesis mechanisms because of speciesspecific characteristics, such as tooth type (only incisors and molars in mice) and number of dentitions (one dentition in mice vs. two dentitions - deciduous and permanent - in humans) [6]. Mutations in PAX9 (Paired Box 9), MSX1 (Msh Homeobox 1), and EDA (Ectodysplasin A), have been shown to cause arrest of tooth development in mice and humans, and these genes have been extensively studied [1-10]. 


\begin{tabular}{|c|c|c|c|c|c|c|}
\hline Family No. & Individual No. & Phenotype & Relationship & $\begin{array}{c}\text { No. of } \\
\text { Missing } \\
\text { Teeth }\end{array}$ & Type of Missing Teeth & Inheritance \\
\hline \multirow[t]{4}{*}{5} & $5-1$ & Oligodontia & Proband & 13 & Incisors, premolars & $\mathrm{AR}$ \\
\hline & $5-2$ & Unaffected & Mother & 0 & & \\
\hline & $5-3$ & Unaffected & Father & 0 & & \\
\hline & $5-4$ & Unaffected & Sister & 0 & & \\
\hline \multirow[t]{4}{*}{6} & $6-1$ & Oligodontia & Proband & 23 & Incisors, premolars, molars & Complex \\
\hline & $6-2$ & Hypodontia & Mother & 2 & Upper lateral incisors & \\
\hline & $6-3$ & Unaffected & Father & 0 & & \\
\hline & $6-4$ & Unaffected & Brother & 0 & & \\
\hline \multirow[t]{4}{*}{7} & $7-1$ & Oligodontia & Proband & 17 & Incisors, premolars, molars & $\mathrm{AR}$ \\
\hline & $7-2$ & Unaffected & Mother & 0 & & \\
\hline & $7-3$ & Unaffected & Father & 0 & & \\
\hline & $7-4$ & Unaffected & Sister & 0 & & \\
\hline \multirow[t]{3}{*}{8} & $8-1$ & Oligodontia & Proband & 9 & Incisors, premolars & $\mathrm{AD}$ \\
\hline & $8-2$ & Unaffected & Mother & 0 & & \\
\hline & $8-3$ & Hypodontia & Father & 2 & Upper lateral incisors & \\
\hline \multirow[t]{8}{*}{9} & $9-1$ & Oligodontia & Proband & 15 & Incisors, premolars, molars & Complex \\
\hline & $9-2$ & Unaffected & Mother & 0 & & \\
\hline & $9-3$ & Hypodontia & Father & Unk & & \\
\hline & $9-4$ & Hypodontia & Brother & Unk & & \\
\hline & $9-5$ & Hypodontia & Brother & Unk & & \\
\hline & $9-6$ & Unaffected & Sister & 0 & & \\
\hline & $9-7$ & Unaffected & Brother & 0 & & \\
\hline & $9-8$ & Unaffected & Sister & 0 & & \\
\hline \multirow[t]{5}{*}{10} & $10-1$ & Oligodontia & Proband & 9 & Incisors, premolars, molars & X-linked \\
\hline & $10-2$ & Unaffected & Mother & 0 & & \\
\hline & $10-3$ & Hypodontia & Father & 3 & & \\
\hline & $10-4$ & Hypodontia & Sister & 4 & & \\
\hline & $10-5$ & Unaffected & Brother & 0 & & \\
\hline \multirow[t]{4}{*}{11} & $11-1$ & Oligodontia & Proband & 8 & Incisors, canines, premolars & AR \\
\hline & $11-2$ & Unaffected & Mother & 0 & & \\
\hline & $11-3$ & Unaffected & Father & 0 & & \\
\hline & $11-4$ & Unaffected & Sister & 0 & & \\
\hline \multirow[t]{5}{*}{12} & $12-1$ & Oligodontia & Proband & 12 & Incisors and premolars & $\mathrm{AD}$ \\
\hline & $12-2$ & Oligodontia & Mother & Unk & & \\
\hline & $12-3$ & Unaffected & Father & 0 & & \\
\hline & $12-4$ & Unaffected & Brother & 0 & & \\
\hline & $12-5$ & Oligodontia & Uncle & 12 & & \\
\hline \multirow[t]{4}{*}{13} & $13-1$ & Oligodontia & Proband & 12 & Incisors, canines, molars & $\mathrm{AR}$ \\
\hline & $13-2$ & Unaffected & Mother & 0 & & \\
\hline & $13-3$ & Oligodontia & Father & 7 & & \\
\hline & $13-4$ & Oligodontia & Brother & 8 & & \\
\hline
\end{tabular}

mouse tooth development strongly implicated this gene family in the etiology of tooth agenesis [11-14]. In recent years, mutations in WNT pathway genes, namely AXIN2 (Axis Inhibition Protein 2), WNT10A (Wingless-Type MMTV Integration Site Family, Member 10A), LRP6 (lowdensity lipoprotein receptorrelated protein 6), and recently WNT10B (Wingless-Type MMTV Integration Site Family, Member 10B), have also been shown to cause tooth agenesis in humans $[8,10,15$ 18]. Additional studies have also shown the association of common single nucleotide polymorphisms in a few WNT pathway genes with the milder form of tooth agenesis, hypodontia [19-22]. However, the associa-

The WNT gene pathway regulates multiple developmental processes during craniofacial and tooth development [11-12]. Previous evidence showing the expression of several Wnt genes during tion of WNT pathway gene polymorphisms in oligodontia pheno- 


\begin{tabular}{|c|c|c|c|c|c|c|}
\hline Family No. & Individual No. & Phenotype & Relationship & $\begin{array}{c}\text { No. of } \\
\text { Missing } \\
\text { Teeth }\end{array}$ & Type of Missing Teeth & Inheritance \\
\hline \multirow[t]{7}{*}{14} & $14-1$ & Oligodontia & Proband & 12 & Incisors and premolars & Complex \\
\hline & $14-2$ & Hypodontia & Mother & 4 & & \\
\hline & $14-3$ & Unaffected & Father & 0 & & \\
\hline & $14-4$ & Hypodontia & Brother & 4 & & \\
\hline & $14-5$ & Hypodontia & Cousin & 2 & Upper lateral incisors & \\
\hline & $14-6$ & Unaffected & Uncle & 0 & & \\
\hline & $14-7$ & Hypodontia & Uncle's wife & 2 & Upper lateral incisors & \\
\hline \multirow[t]{7}{*}{15} & $15-1$ & Oligodontia & Proband & 7 & Premolars, molars & Complex \\
\hline & $15-2$ & Unaffected & Mother & 0 & & \\
\hline & $15-3$ & Hypodontia & Father & 2 & Upper lateral incisors & \\
\hline & $15-4$ & Unaffected & Sister & 0 & & \\
\hline & $15-5$ & Hypodontia & Uncle & 2 & Upper lateral incisors & \\
\hline & $15-6$ & Hypodontia & Uncle & 1 & Upper lateral incisor & \\
\hline & $15-7$ & Hypodontia & Uncle & 1 & Upper lateral incisor & \\
\hline \multirow[t]{4}{*}{16} & $16-1$ & Oligodontia & Proband & 10 & $\begin{array}{l}\text { Incisors, canines, premolars, } \\
\text { molars }\end{array}$ & $\mathrm{AD}$ \\
\hline & $16-2$ & Unaffected & Mother & 0 & & \\
\hline & $16-3$ & Unaffected & Father & 0 & & \\
\hline & $16-4$ & Unaffected & Brother & 0 & & \\
\hline \multirow[t]{5}{*}{17} & $17-1$ & Oligodontia & Proband & 6 & $\begin{array}{c}\text { Upper lateral incisors, } \\
\text { premolars }\end{array}$ & $\mathrm{AR}$ \\
\hline & $17-2$ & Unaffected & Mother & 0 & & \\
\hline & $17-3$ & Hypodontia & Father & 2 & Upper lateral incisors & \\
\hline & $17-4$ & Unaffected & Brother & 0 & & \\
\hline & $17-5$ & Hypodontia & Sister & 4 & Premolars & \\
\hline \multirow[t]{4}{*}{18} & $18-1$ & Oligodontia & Proband & 18 & Incisors, premolars, molars & $\mathrm{AD}$ \\
\hline & $18-2$ & Unaffected & Mother & 0 & & \\
\hline & $18-3$ & Unaffected & Father & 0 & & \\
\hline & $18-4$ & Oligodontia & Sister & 28 & $\begin{array}{l}\text { Incisors, canines, premolars, } \\
\text { molars }\end{array}$ & \\
\hline \multirow[t]{3}{*}{19} & $19-1$ & Oligodontia & Proband & 10 & Incisors and premolars & Complex \\
\hline & $19-2$ & Hypodontia & Mother & 2 & Upper lateral incisors & \\
\hline & $19-3$ & Unaffected & Father & 0 & & \\
\hline \multirow[t]{2}{*}{20} & $20-1$ & Oligodontia & Proband & 13 & & $\mathrm{AD}$ \\
\hline & $20-2$ & Unaffected & Mother & 0 & & \\
\hline \multirow[t]{3}{*}{21} & $21-1$ & Oligodontia & Proband & 28 & $\begin{array}{l}\text { Incisors, canines, premolars, } \\
\text { molars }\end{array}$ & Complex \\
\hline & $21-2$ & Unaffected & Mother & 0 & & \\
\hline & $21-3$ & Unaffected & Father & 0 & & \\
\hline \multirow[t]{3}{*}{22} & $22-1$ & Oligodontia & Proband & 16 & $\begin{array}{l}\text { Incisors, canines, premolars, } \\
\text { molars }\end{array}$ & Complex \\
\hline & $22-2$ & Hypodontia & Mother & 2 & Upper lateral incisors & \\
\hline & $22-3$ & Unaffected & Father & 0 & & \\
\hline
\end{tabular}

\section{Material and methods}

Sample Population

This

study was approved by the Istanbul University Institutional Ethical Review Board and the Committee for Protection of Human Subjects at the University of Texas Health Science Center at Houston. Clinical and demographic information and DNA samples from peripheral blood were obtained from the CRANIRARE2 Project, an European Union-funded colloborative ERAnet Project on craniofacial malformations run at the Istanbul University, Istanbul Medical Faculty, Medical Genetics Department. All registry participants had signed an informed

types is still unclear. Therefore, in this study, we investigated the association of single nucleotide pol- ymorphisms in 12 WNT pathway genes with oligodontia in multiplex families from Turkey. consent form agreeing to participate in genetic studies and pro- 


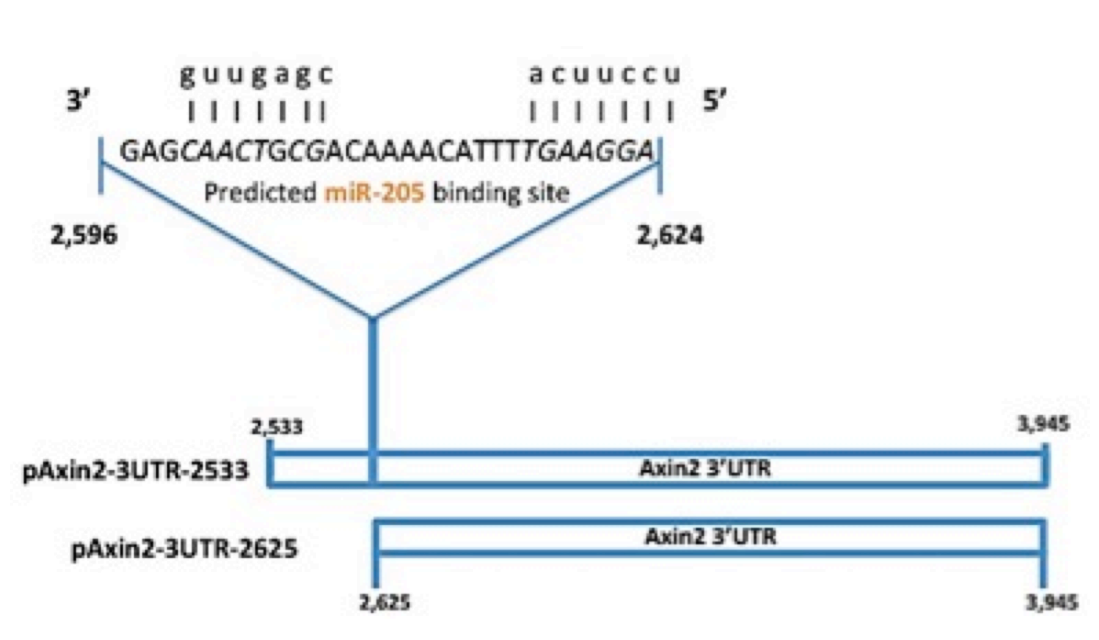

Figure 1. $A X I N 2$ rs7591 is predicted to bind to miR-205-5p.

vided a blood samples as a source of genomic DNA.

Probands were selected from the registry based on their radiographic records showing congenital tooth agenesis and were invited to participate. Individuals were considered to have oligodontia when six or more permanent teeth were missing in the oral cavity, excluding third molars. Families were ascertained through probands, and additional relatives were recruited. All probands and available family members were further examined clinically to confirm the tooth agenesis status and exclude syndromic cases. In a few cases, history of tooth agenesis was available by self-report from family members, or from statements by their dental provider. Our sample population consisted of 22 multiplex oligodontia families (117 total individuals, 67 affected, 50 unaffected), in which tooth agenesis segregated in both autosomal dominant and autosomal recessive forms, and an average of 2-18 teeth were missing in each affected individual. Details of studied families are presented in Table 1.

\section{Selection of Candidate Genes and Single Nucleotide Polymorphisms}

We selected 37 single nucleotide polymorphisms (SNPs) in/nearby $A P C, A X I N 1, A X I N 2$, LRP5, LRP6, WNT3, WNT3A, WNT5A, WNT8A, WNT9B, WNT10A, and WNT11 genes for genotyping in our families. SNPS were selected based on their locations within the genes, on their likelihood to have functional consequences (i.e., located in the promoters, exons, or near exon/intron boundaries), or if considered tag-SNPs for the linkage disequilibrium blocks surrounding the respective genes [23]. We used information available at the NCBI dbSNP

(http://www.ncbi.nlm.gov/SNP/) and HapMap Project (http://www.hapmap.org) databases to select polymorphisms. Details of studied genes and polymorphisms are presented in Table 2 .

\section{Genotyping}

Genomic DNA was extracted from blood using established protocols. Genotypes were generated using Taqman chemistry [24]. Reactions were carried out in $5-\mu \mathrm{L}$ volumes in a ViiA7 Sequence Detection System (Applied Biosystems, Foster City, CA). Assays and reagents were supplied by Applied Biosystems. The results were analyzed using EDS software (Applied Biosystems). In order to ensure quality control of genotyping reactions, we included a non-template control (water instead of DNA) as negative control and a DNA sample of known genotype as positive control in each reaction.

\section{Association analyses}

Family-based association tests were performed using FBAT software version 1.06 [25]. We used Bonferroni correction to adjust for multiple testing (0.05/37) and $\mathrm{P}$-values $\leq 0.001$ were considered significant.

\section{In silico prediction of SNP function}

We performed in silico analysis of SNP function to predict the effects of the associated AXIN2 rs7591 SNPs function using MiRBase software [26].

\section{Results}

\section{Association analyses}

We found evidence of altered allelic transmission for AXIN2 rs7591, in the gene 3' UTR, with oligodontia $(P=0.04)$. 
Dentistr

Vol 4, No 1 (2016) DOI 10.5195/d3000.2016.57

\section{In silico prediction of SNP function}

In silico analysis of the 3' UTR SNP in AXIN2 rs7591 predicted a binding site for the microRNA miR-205-5p with potential effects on gene expression (Figure 1).

\section{Discussion}

In this study, we investigated the association of 12 WNT pathway genes (APC, AXIN1, AXIN2, LRP5, LRP6, WNT3, WNT3A, WNT5A, WNT8A, WNT9B, WNT10A, and WNT11) with nonsyndromic oligodontia in 22 wellcharacterized Turkish Caucasian multiplex families. Although modest, our results suggest a positive association between AXIN2 and oligodontia, and corroborate the results of previous studies [19-21]. To our knowledge, this is the most comprehensive analysis of the association of WNT/ $\beta$-catenin pathway genes with tooth agenesis, particularly oligodontia.

Over the years, many signaling pathways have shown to be involved in the organogenesis and embryogenesis of teeth $[3,5,7$, $12,27]$. Individuals with oligodontia constitute approximately $1 \%$ of all individuals with hypodontia, and both conditions can be found in the same family, indicating variable expression of shared genetic factors $[2,7]$. The importance of the WNT/ $\beta$-catenin signaling pathway during tooth development has been reported by several authors [11-14]. Many studies showed that Wnt pathway plays a critical role in tooth morphogenesis and several Wnt genes are expressed in craniofacial and dental tissues [11-14]. Wnt pathway activation has roles at the laminaearly bud stage and also important for molar cusps development [13]. During tooth development, AXIN2 is expressed in the dental mesenchyme, the odontoblasts and the enamel knot, and it is needed as a negative regulator of WNTsignaling at specific stages $[12$, 13].

\section{Additional common vari-} ants in AXIN2 have also been associated with increased susceptibility to hypodontia in Eastern Europeans [19]. However, the SNP associated in the present study, rs 7591, located in the 3' UTR, has not been previously reported in association with tooth agenesis and warrants additional confirmatory studies. Previously, this same SNP was reported in association with oral clefts in families with increased susceptibility to colon cancer [28, 29]. Interestingly, in silico analyses predicted that this SNP harbors a binding site for the miR-205-5p, with a potential regulatory role in gene expression. Recent evidence has shown that a number of cellular functions, including development, differentiation, growth, metabolism, anabolism, and carcinogenesis can be affected by miRNA functions [30]. Although the role of miR-205-5p in craniofacial development is yet unknown, it has been suggested to play a role in cancer development and Parkinson's disease [31]. Further, the level of miR-205-5p expression was found to be downregulated in various cancer cells, including breast, oral, prostate cancer cells, and melanoma [32].
Additional studies on miR-205-5p and its effect on the regulation of AXIN2 might elucidate the role of these molecules in tooth agenesis.

In addition to a critical role in embryonic development, the WNT/ $\beta$-catenin signaling pathway is also associated with tumorigenesis events [9]. Mutations in AXIN2 were found segregating with autosomal dominant tooth agenesis and colorectal cancer in a large multiplex family, suggesting that a same gene may be involved in congenital anomalies and cancer later in life [15]. AXIN2 mutations were also detected segregating in autosomal dominant pattern with oligodontia and other findings including colonic polyposis, gastric polyps, a mild ectodermal dysplasia phenotype with sparse hair and eyebrows, and early onset colorectal and breast cancers [33]. The AXIN2 gene encodes the axis inhibition protein 2 that regulates the stability of beta-catenin and early organ differentiation and development and plays a key role in many basic cell functions, like cell homeostasis [9]. Since the report by Lammi et al. [15], numerous human genetic studies have focused on identifying variants in AXIN2 in association with tooth agenesis or other birth defects such as cleft lip/palate [8-10, 19$21,28]$, due to the previously suggested hypothesis that cancerrelated genes may have a role in tooth agenesis. Notwithstanding, despite the positive associations reported, additional studies are needed to determine if potential correlations exist between AXIN2, birth defects and cancer. 
Recently, WNT10A has been suggested as a major candidate gene for tooth agenesis, and oligodontia in particular, and rare variants in this gene have been found in individuals with tooth agenesis from multiple populations [33]. Interestingly, in the present study, we did not identify any association between common variants in WNT10A and oligodontia in our Turkish families.

In summary, although modest, our results continue to support a role for $A X I N 2$ and the $\mathrm{WNT} / \beta$-catenin signaling pathway in human tooth agenesis. Discrepancies between the present and previous studies may be due to heterogeneity of the condition across distinct populations, and/or the common variant-common disease approach used in this association study, when rare variants in relevant genes could be the cause of the phenotype. Future studies should focus on the identification of potentially functional variants in AXIN2 and additional WNT pathway genes to further establish a biological role of this pathway in tooth agenesis phenotypes.

\section{Acknowledgements}

We would like to thank all of the participating patients and their families for their support in this research. This work partially supported by Research Fund of Istanbul University; Project num-

\begin{tabular}{|c|c|c|c|c|c|c|c|}
\hline SNP & Locus & Gene & Function & Alleles* & MAF & Informative families** & P-value*** \\
\hline rs861674 & Chr.5: 112064475 & $A P C$ & Intron & $\mathrm{A} / \mathrm{T}$ & 0.454 & 17 & 0.67 \\
\hline rs2431238 & Chr.5: 112124369 & $A P C$ & Intron & $\mathrm{C} / \mathrm{T}$ & 0.343 & 14 & 1 \\
\hline rs454886 & Chr.5: 112146117 & $A P C$ & Intron & $\mathrm{C} / \mathrm{T}$ & 0.348 & 18 & 0.65 \\
\hline rs351771 & Chr.5: 112164561 & $A P C$ & Synonymous & $\mathrm{C} / \mathrm{T}$ & 0.009 & 1 & --- \\
\hline rs448475 & Chr.5: 112181379 & $A P C$ & 3' UTR & $\mathrm{C} / \mathrm{G}$ & 0.482 & 18 & 0.67 \\
\hline rs2301522 & Chr.16: 359953 & AXIN1 & Intron & $\mathrm{A} / \mathrm{G}$ & 0.4 & 16 & 0.5 \\
\hline rs7591 & Chr.17: 63525082 & AXIN2 & 3' UTR & $\mathrm{A} / \mathrm{T}$ & 0.143 & 11 & 0.04 \\
\hline rs7224837 & Chr.17: 63528123 & AXIN2 & Intron & $\mathrm{A} / \mathrm{G}$ & 0.491 & 23 & 0.91 \\
\hline rs11867417 & Chr.17: 63537898 & AXIN2 & Intron & $\mathrm{C} / \mathrm{T}$ & 0.201 & 13 & 0.84 \\
\hline rs3923086 & Chr.17: 63549488 & AXIN2 & Intron & $\mathrm{G} / \mathrm{T}$ & 0.438 & 18 & 0.43 \\
\hline rs2240307 & Chr.17: 63554307 & AXIN2 & Intron & $\mathrm{A} / \mathrm{G}$ & 0.179 & 7 & 0.28 \\
\hline rs740026 & Chr.17: 63561681 & AXIN2 & Intergenic & $\mathrm{A} / \mathrm{G}$ & 0.232 & 14 & 0.86 \\
\hline rs634008 & Chr.11: 68094741 & $L R P 5$ & Intron & $\mathrm{C} / \mathrm{T}$ & 0.402 & 20 & 0.46 \\
\hline rs667126 & Chr.11: 68177728 & $L R P 5$ & Intron & $\mathrm{C} / \mathrm{T}$ & 0.267 & 16 & 0.29 \\
\hline rs312788 & Chr.11: 68122295 & $L R P 5$ & Intron & $\mathrm{G} / \mathrm{T}$ & 0.384 & 20 & 0.57 \\
\hline rs312014 & Chr.11: 68084962 & $L R P 5$ & Intron & $\mathrm{C} / \mathrm{G}$ & 0.438 & 17 & 0.77 \\
\hline rs10743980 & Chr.12: 12412795 & LRP6 & Intron & $\mathrm{C} / \mathrm{T}$ & 0.438 & 17 & 0.45 \\
\hline rs4477532 & Chr.12: 12279361 & LRP6 & Intron & $\mathrm{A} / \mathrm{G}$ & 0.037 & 4 & --- \\
\hline rs7294695 & Chr.12: 12323618 & LRP6 & Intron & $\mathrm{C} / \mathrm{G}$ & 0.393 & 20 & 0.65 \\
\hline rs121908120 & Chr.2: 218890289 & WNT10A & Missense & $\mathrm{A} / \mathrm{T}$ & 1 & 0 & --- \\
\hline rs3806557 & Chr.2: 218879152 & WNT10A & Missense & $\mathrm{A} / \mathrm{G}$ & 0.009 & 1 & --- \\
\hline rs199980023 & Chr.2: 218882196 & WNT10A & Missense & $\mathrm{C} / \mathrm{T}$ & 0.5 & 22 & 0.81 \\
\hline rs116998555 & Chr.2: 218890118 & WNT10A & Missense & $\mathrm{C} / \mathrm{T}$ & 0.009 & 1 & $-\cdots$ \\
\hline rs4574113 & Chr.2: 219762662 & WNT10A & Intron & $\mathrm{A} / \mathrm{T}$ & 0.194 & 11 & 1 \\
\hline rs10177996 & Chr.2: 219746561 & WNT10A & Intron & $\mathrm{C} / \mathrm{T}$ & 0.223 & 12 & 0.41 \\
\hline rs3806557 & Chr.2: 219743874 & WNT10A & Intron & $\mathrm{G} / \mathrm{A}$ & 0.221 & 12 & 0.33 \\
\hline rs1533767 & Chr.11: 75905800 & WNT11 & Intron & $\mathrm{A} / \mathrm{G}$ & 0.009 & 1 & $-\cdots-$ \\
\hline rs199498 & Chr.17: 44865603 & WNT3 & Intergenic & $\mathrm{C} / \mathrm{T}$ & 1 & 0 & $-\cdots$ \\
\hline rs111769 & Chr.17: 44871987 & WNT3 & Intergenic & $\mathrm{C} / \mathrm{T}$ & 0.356 & 19 & 0.31 \\
\hline rs9890413 & Chr.17: 44901449 & WNT3 & Intergenic & $\mathrm{A} / \mathrm{G}$ & 0.356 & 14 & 0.6 \\
\hline rs708111 & Chr.1: 228191365 & WNT3A & Intergenic & $\mathrm{C} / \mathrm{T}$ & 0.143 & 13 & 0.5 \\
\hline rs3094912 & Chr.1: 228209815 & WNT3A & Intron & $\mathrm{A} / \mathrm{T}$ & 0.38 & 18 & 0.24 \\
\hline rs752107 & Chr.1: 228247351 & WNT3A & 3' UTR & $\mathrm{C} / \mathrm{T}$ & 0.256 & 13 & 0.23 \\
\hline rs1745420 & Chr.1: 228251732 & WNT3A & Intergenic & $\mathrm{C} / \mathrm{G}$ & 0.393 & 22 & 0.15 \\
\hline rs566926 & Chr.3: 55520778 & WNT5A & Intron & $\mathrm{A} / \mathrm{C}$ & 0.348 & 18 & 0.41 \\
\hline rs2040862 & Chr.5: 137419989 & WNT8A & Intron & $\mathrm{C} / \mathrm{T}$ & 0.446 & 23 & 0.9 \\
\hline rs2165846 & Chr.17: 44941366 & WNT9B & Intron & $\mathrm{A} / \mathrm{G}$ & 0.5 & 18 & 0.64 \\
\hline
\end{tabular}

ber 48398, and from the Scientific and Technological Research Council of Turkey (TUBITAK), grant number 112S398 [CRANIRARE-2].

\section{References}

1. Genetic basis of tooth agenesis. Nieminen P. J Exp Zool B
Mol Dev Evol. 2009 Jun

15;312B(4):320-42. PMID:19219933.

2. A meta-analysis of the prevalence of dental agenesis of permanent teeth. Polder BJ, Van't Hof MA, Van der Linden FP, Kuijpers-Jagtman AM. Community 
Dent Oral Epidemiol. 2004 Jun;32(3):217-26. PMID: 15151692.

3. Tooth agenesis: from molecular genetics to molecular dentistry. Matalova E, Fleischmannova J, Sharpe PT, Tucker AS. J Dent Res. 2008 Jul;87(7):617-23. PMID: 18573979.

4. Anomalies associated with hypodontia of the permanent lateral incisor and second premolar. Symons AL, Stritzel F, Stamation J. J Clin Pediatr Dent. 1993 Winter;17(2):109-11. PMID: 8466838.

5. Tooth morphogenesis and cell differentiation. Thesleff I, Nieminen P. Curr Opin Cell Biol. 1996 Dec;8(6):844-50. PMID: 8939666.

6. Two genes for missing teeth. Thesleff I. Nat Genet. 1996 Aug;13(4):379-80. PMID: 8696323.

7. The genetic basis of inherited anomalies of the teeth. Part 1: clinical and molecular aspects of non-syndromic dental disorders. Bailleul-Forestier I, Molla M, Verloes A, Berdal A. Eur J Med Genet. 2008 Jul-Aug;51(4):273-91. PMID: 18499550.

8. Isolated oligodontia associated with mutations in EDARADD, AXIN2, MSX1, and PAX9 genes. Bergendal B, Klar J, Stecksén-Blicks C, Norderyd J, Dahl N. Am J Med Genet A. 2011 Jul;155A(7):1616-22. PMID: 21626677.

9. Exclusion of coding region mutations in MSX1, PAX9 and AXIN2 in eight patients with severe oligodontia phenotype. Gerits A, Nieminen P, DE Muynck S, Carels C. Orthod Craniofac Res. 2006 Aug;9(3):129-36. PMID: 16918677.

10. Mutational analysis of AXIN2, MSX1, and PAX9 in two Mexican oligodontia families. Mu YD, $\mathrm{Xu} \mathrm{Z}$, Contreras $\mathrm{Cl}, \mathrm{McDaniel} \mathrm{JS}$, Donly KJ, Chen S. Genet Mol Res. 2013 Oct 10;12(4):4446-58. PMID: 24222224.

11. Expression of Wnt signaling pathway genes during tooth development. Sarkar L, Sharpe PT. Mech Dev. 1999 Jul;85(1-2):197200. PMID: 10415363.

\section{Expression patterns of} WNT/ $\beta$-CATENIN signaling molecules during human tooth development. Wang B, Li H, Liu Y, Lin X, Lin Y, Wang Y, Hu X, Zhang Y. J Mol Histol. 2014 Oct;45(5):487-96. PMID: 24647585.

13. Wnt/beta-catenin signaling directs multiple stages of tooth morphogenesis. Liu F, Chu EY, Watt B, Zhang Y, Gallant NM, Andl T, Yang SH, Lu MM, Piccolo S, Schmidt-Ullrich R, Taketo MM, Morrisey EE, Atit R, Dlugosz AA, Millar SE. Dev Biol. 2008 Jan 1;313(1):210-24. PMID: 18022614

14. Wnt5a plays a crucial role in determining tooth size during murine tooth development. Cai J, Mutoh N, Shin JO, Tani-Ishii N, Ohshima H, Cho SW, Jung HS. Cell Tissue Res. 2011 Sep;345(3):36777. PMID: 21879290.

15. Mutations in AXIN2 cause familial tooth agenesis and predispose to colorectal cancer. Lammi L, Arte S, Somer M, Jarvinen H,
Lahermo P, Thesleff I, Pirinen S, Nieminen P. Am J Hum Genet. 2004 May;74(5):1043-50. PMID: 15042511.

16. Mutations in WNT10A are present in more than half of isolated hypodontia cases. van den Boogaard MJ, Créton $M$, Bronkhorst $Y$, van der Hout $A$, Hennekam E, Lindhout D, Cune $M$, Ploos van Amstel HK. J Med Genet. 2012 May;49(5):327-31. PMID: 22581971.

17. Loss-of-Function Mutations in the WNT Co-receptor LRP6 Cause Autosomal-Dominant Oligodontia. Massink MP, Créton MA, Spanevello F, Fennis WM, Cune MS, Savelberg SM, Nijman IJ, Maurice $\mathrm{MM}$, van den Boogaard MJ, van Haaften G. Am J Hum Genet. 2015 Oct 1;97(4):621-6. PMID: 26387593.

18. Mutations in WNT10B Are Identified in Individuals with Oligodontia. Yu P, Yang W, Han D, Wang X, Guo S, Li J, Li F, Zhang X, Wong SW, Bai B, Liu Y, Du J, Sun ZS, Shi S, Feng H, Cai T. Am J Hum Genet. 2016 Jul 7;99(1):195-201. PMID: 27321946.

19. Axis inhibition protein 2 (AXIN2) polymorphisms may be a risk factor for selective tooth agenesis. Mostowska A, Biedziak $B$, Jagodzinski PP. J Hum Genet. 2006;51(3):262-6. PMID: 16432638.

20. AXIN2 and CDH1 polymorphisms, tooth agenesis, and oral clefts. Letra A, Menezes R, Granjeiro JM, Vieira AR. Birth Defects Res A Clin Mol Teratol. 2009 
Feb;85(2):169-73. PMID: 18683894.

21. Axis inhibition protein 2 (AXIN2) polymorphisms and tooth agenesis. Callahan N, Modesto A, Meira R, Seymen F, Patir A, Vieira AR. Arch Oral Biol. 2009 Jan;54(1):45-9. PMID: 18790474.

22. Nucleotide variants of genes encoding components of the Wnt signaling pathway and the risk of non-syndromic tooth agenesis. Mostowska A, Biedziak B, Zadurska M, Dunin-Wilczynska I, Lianeri $\mathrm{M}$, Jagodzinski PP. Clin Genet. 2013 Nov;84(5):429-40. PMID: 23167694.

23. Selecting a maximally informative set of single-nucleotide polymorphisms for association analyses using linkage disequilibrium. Carlson CS, Eberle MA, Rieder MJ, Yi Q, Kruglyak L, Nickerson DA. Am J Hum Genet. 2004 Jan;74(1):106-20. PMID: 14681826.

24. High-throughput genotyping with single nucleotide polymorphisms. Ranade K, Chang MS, Ting CT, Pei D, Hsiao CF, Olivier $M$, Pesich R, Hebert J, Chen YD, Dzau VJ, Curb D, Olshen R, Risch N, Cox DR, Botstein D. Genome Res. 2001 Jul;11(7):1262-8. PMID: 11435409.

25. Family-based tests of association in the presence of linkage. Lake SL, Blacker D, Laird NM. Am J Hum Genet. 2000 Dec;67(6):151525. PMID: 11058432.

26. miRBase: the microRNA sequence database. Griffiths-Jones S. Methods Mol Biol.
2006;342:129-38. PMID: 16957372.

27. Genetic basis for tooth malformations: from mice to men and back again. Mitsiadis TA, Luder HU. Clin Genet. 2011 Oct;80(4):319-29. PMID: 21819395.

28. AXIS inhibition protein 2, orofacial clefts and a family history of cancer. Menezes R, Marazita ML, Goldstein McHenry T, Cooper $\mathrm{ME}$, Bardi $\mathrm{K}$, Brandon C, Letra A, Martin RA, Vieira AR. J Am Dent Assoc. 2009 Jan;140(1):80-4. PMID:19119171.

29. The axis inhibition protein 2 polymorphisms and nonsyndromic orofacial clefts susceptibility in a Chinese Han population. Han Y, Zhou L, Ma L, Li D, Xu $M$, Yuan $H$, Ma J, Zhang $W$, Jiang $\mathrm{H}$, Wu Y, Wang L, Pan Y. J Oral Pathol Med. 2014 Aug;43(7):55460. PMID: 24484320.

30. MicroRNAs in Human Diseases: From Cancer to Cardiovascular Disease. Ha TY. Immune Netw. 2011 Jun;11(3):135-54. PMID: 21860607.

31. A program of microRNAs controls osteogenic lineage progression by targeting transcription factor Runx2. Zhang Y, Xie RL, Croce CM, Stein JL, Lian JB, van Wijnen AJ, Stein GS. Proc Natl Acad Sci U S A. 2011 Jun 14;108(24):9863-8. PMID: 21628588.

32. MicroRNA-205 suppresses the oral carcinoma oncogenic activity via down-regulation of Axin2 in KB human oral cancer cell.
Kim JS, Park SY, Lee SA, Park MG, Yu SK, Lee MH, Park MR, Kim SG, Oh JS, Lee SY, Kim CS, Kim HJ, Chun HS, Kim JS, Moon SM, Kim DK. Mol Cell Biochem. 2014 Feb;387(1-2):71-9. PMID: 24166197.

33. AXIN2-associated autosomal dominant ectodermal dysplasia and neoplastic syndrome. Marvin ML, Mazzoni SM, Herron CM, Edwards S, Gruber SB, Petty EM. Am J Med Genet A. 2011 Apr;155A(4):898-902. PMID: 21416598

34. WNT10A variants are associated with non-syndromic tooth agenesis in the general population. Song S, Zhao R, He H, Zhang J, Feng $\mathrm{H}$, Lin L. Hum Genet. 2014 Jan;133(1):117-24. PMID: 24043634 